\title{
MELODRAMA STYLE DESCRIPTION OF FEMALE IMAGES AND THEIR FATE IN THE UKRAINIAN AND THE ENGLISH PROSE (G. KVITKA-OSNOVIANENKO "MARUSYA" AND CH. DICKENS "DOMBEY AND SON" IN THE COMPARATIVE TYPOLOGIAL ASPECT)
}

Summary. Profound research of the literary phenomena of different cultures for analysis is always a plentiful subject for the study which can give us understanding that literary process reflects the contemporary reality with its social, psychological aspects and their penetration into works of arts has a uniqueness which is of a special interest. Quotations of scholars concerning some writers belong to the contact-genetic ties and give the researcher an impulse for the study of the literary works on the typological level. Such an uttering of the Ukrainian literary critic P. Kulish reveal some ties and give us the basis for the research. Thus, the aim of the article is to find some similar and different features of melodrama style prose by G. Kvitka-Osnovianenko "Marusya" and Ch. Dickens "Dombey and Son". These prose works are different in genre (a short story and a novel) and in size but common features of melodrama style give us a chance to regard them on the typological-comparative level.

The English and Ukrainian writes were almost contemporaries (Ch. Dickens 1812-1870; G. Kvitka 17781843), so it is not surprisingly that their works are characterized by similar features of melodrama and sentimentality which were gained due to the "social" and "psychological" aspects of reality which is authors' love for the theater. The main characters of the analyzed works are female characters: Marusya and Florence, who are very similar in inner features such as impracticality, bad adaptation to life, dreaminess, moral purity, emotional admiration by good things. This is a special type of literary character of a woman who should play no political role in the society and only stay at home. The motives: birth, relationship with parents, love, family collisions, death belong to the topics of the melodrama style prose; the transmission of the emotional state through the statements, actions, movements, gestures, eye expressions, facial expressions make the reader penetrate into the feelings of characters and a melodramatic effect is created - the audience unconsciously becomes a part of the actions.

Key words: contact-genetic ties, typological level, melodrama style, sentimentality, ontological themes.

Reflection on the world cultural heritage of artistic and aesthetic thought in general and a new understanding of the works of the Ukrainian literature in particular in the connection with the former is a priority of the Ukrainian comparative literary studies in recent decades. According to the German scholar Henry G. Remak who worked in the USA: "Literary comparative studies is the study of literature outside one country, as well as the study of the relationship between literature, on the one hand, and other areas of knowledge and beliefs, such as art (for example, painting, sculpture, architecture, music), philosophy, history, social sciences (for example, politics, economics, sociology), science, religion, etc. - on the other hand. In short, it is a comparison of one literature with another or others, as well as a comparison of literature with other areas of human expression" [1, p. 44]. Profound research of the literary phenomena of different cultures taken together for analysis is always a beneficial subject for the further study which can give us understanding that literary process reflects the contemporary reality with its social, economic, psychological aspects and their penetration into works of art and has a unique character which is of a special interest.

Comparative methods, which are based on the study of the contact-genetic connections and typological features (during the theory of D. Diuryshyn) [2] in their organic unity, reveal universal commonalities and national differences, general patterns in the development of the aesthetic phenomena and their artistic originality. Quotations of the literary scholars concerning some writers put in one thought of theirs belong to the contact-genetic ties and give the researcher an impulse for the study of the literary works on the typological level.

Thus, the following quotations urged us to study G. KvitkaOsnovianenko "Marusya" and Ch. Dickens "Dombey and Son" on the comparative level. The Ukrainian writer and literary critic P. Kulish noticed the similarity of the creative style of the Ukrainian artists G. Kvitka-Osnovianenko, M. Gogol and the English novelist Ch. Dickens in the article "On the relationship of Little Russian literature to all-Russian" (1957) where he regards the works of G. Kvitka and assesses his creative method as similar to those who were "the greatest painters of life, customs and human passions, such as Walter Scott, Dickens and our Gogol" [3, p. 492]. Such the uttering of the Ukrainian literary critic P. Kulish reveal some ties and give us the basis for further research.

Thus, the aim of the article is to find some similar and different features of melodrama style prose by G. Kvitka-Osnovianenko "Marusya" and Ch. Dickens "Dombey and Son". These prose works are different in genre (a short story and a novel) and in size but common features of melodrama style give us the chance to investigate them on the typological-comparative level.

The English and Ukrainian writers were almost contemporaries (Ch. Dickens 1812-1870; G. Kvitka 1778-1843), so it is not surprisingly that their works are characterized by common features of melodrama and sentimentality. It should be noted that typological coincidences and differences are mostly due to "sociotypological, literary-typological and psychological-typological 
factors" (D. Diurydyshyn) [2], which had an impact on the work of the compared writers.

So here we have a deal with the "social" and "psychological" aspects that is authors' love for the theater. It is prominent that worldview and aesthetic preferences of the compared writers have some common features and one of them is their passion for the theatrical life. G. Kvitka wrote plays and was in the creative collaboration with the staff of the Kharkiv Theatre; he became one of the first historians of the Ukrainian theatre (article "History of the theatre in Kharkov") and was also convinced that dramatic plays are an effective means of educating and enlightening people. "He was the protogonist of the idea of the society improvement by the reforms and the influence of the means of literature and theatrical art" [4, p. 440]. So that is why he used some of theatrical means in his prose.

Dickens dreamed of becoming a professional actor from a young age, but he only partially realized his desire and played in a family troupe and was an amateur actor. He also helped the theatre financially by investing in the payment of pensions to actors in the theatre fund. In early days of his career Dickens wrote some plays (farces) which were staged but they are not regarded as a strong facet of his heritage. Nevertheless, his prose adopted some theatrical canons to his narrative and these aspects are spoken about in the books of W. Axton (1966) [5] and R. Garis (1965) [6].

The concept of melodrama style belongs to inter-genre in nature and has the ability to transfer from stage to prose. The most emotional moments of the drama belong to melodrama elements, performed with musical accompaniment to touch the soul of the audience, which create favorable conditions for the realization of sensual, emotional pathos. So, it is clear that the literary term of melodrama originally came from the theatre and of course, the love of writers for the theatrical performances left its mark on the artistic style of both the Ukrainian and English authors. Hence the elements of melodrama style are available in their prose.

The main characters of the analyzed works are female characters: Marusya in G. Kvitka short story and Florence in Ch. Dickens novel are very similar in psychological features such as impracticality, bad adaptation to life, dreaminess, moral purity, emotional admiration by good things. This is a special type of literary character of a woman who should play no social-political role in the society and only belong to her home and household. It is notably that Ukrainian critics have paid their attention to such heroines. For example, Lesya Ukrainka rightly remarked in the article "New Perspectives and Old Shadows" ("New Woman" of Western European fiction) that new trends in contemporary literary fashion brought a revival of the women's issue in literature. In her exploration, she divided the array of female images of world literature into certain groups. So separately go "submissive heroines of Schiller, Goethe, Dickens, Pushkin have at least a sense of human dignity, which significantly distances them from the ideal of the silent sheep" [7, p. 78]. A similar opinion about female images in the works of Charles Dickens was expressed by the Ukrainian researcher K. Shakhova. She wrote that the characters who embody the best human traits seem unrealistic, because "the pink and blue colors with which they are depicted are too contrasting with the general dark, gloomy background" [8, p. 18]. We are dealing with a special patriarchal anti-feminist perception of women at that time as an ideal and beautiful being who has no right to vote in male society.

In fact, although mental sensitivity, idealized perception of the world are positive qualities, at the same time they can paralyze the will of the characters to life, which turns into inferiority, as happens with female characters in the studied literary works. The female characters of Marusya and Florence evoke the reader's sympathy, but they are not able to take a decisive step and influence their destiny, their lives depend on the circumstances in which they find themselves. These young ladies are positive, highly moral characters, reminding of fairy-tale characters, and serve as a contrast to negative immoral characters, who often hinder their happiness. These characters depicted as stereotyped moral ethical personalities that are not shown in the development of their inner world due to canons of melodrama.

The effect of melodrama is also reached with the help of created sense of visibility of the image as if it were on the theatrical stage. In the story "Marusya" the image of Marusya is the ideal maiden with natural beauty, obedience and rich inner world. Naum and Nastya's daughter was "tall, straight like an arrow, black eyes like thorny berries, eyebrows like a lace, red face like a gentleman's rose, which blooms in the garden..." [9, p. 46]. She was dressed in the best clothes: "the shirt on her is white, thin, she spun it by herself and embroidered lush sleeves with red threads" [9, p. 46]. Such portrait characteristics delight the reader's thoughts, and the figure of the character in all its beauty immediately appears in one's imagination as if a stage image was shown.

On the contrary in Dickens's "Dombey and Son" little attention was paid to the description of Florence's appearance. Dickens only wrote: "Such a child was merely a piece of a base coin that couldn't be invested - a bad Boy - nothing more" $[10 ; 13]$ and such a comparison with a little coin was made purposefully to underline the meaningless essence of the girl's existence. Though German researcher Charlotte Ljustina noticed that "Florence's stunning physical beauty and innate lovability allow her to hold the power that makes her father feel fearful and threatened by her. No character of this novel is immune to this power - not even Mr. Dombey in all his strength and sternness" [11]. So this is a very relevant remark and the image really engraves the bright imprint in the reader imagination as something seemingly meaningless though being worthy of great attention.

The Ukrainian short story describes a touching and tragic love story of a country girl and a city boy. In the flow of the linear unfolding of the story, the image of Marusya is increasingly delineated. At the wedding of her friend Marusya falls in love with Vasyl. This love was mutual: "I still don't hear anything, I don't see anything, only this black-eyed girl! She is in front of my eyes and in my mind!" [9, p. 51]. So, the author shows us the possibility of happy end and reader is expecting the continuation. Though emotionally condensed text brings its reader to an unexpected turnabout when love is gradually changed by misfortune and later on death of the main heroin due to the features of melodrama style prose. It is needed to remark that the melodrama has a sentimental orientation: moral and didactic tendencies, excessive emotionality of the characters and a fascinating plot with a sharp intrigue and an unexpected outcome.

Kvitka, as a skilled psychologist, reproducing gestures, facial expressions, movements, mood and emotions in a specific situation, conveys the experiences of the characters through external manifestations: "as if a fever had frightened Vasyl: he was as pale as a sheet, and he grabbed the carriage with his hands so as not to fall from grief" [9, p. 52]. A young boy deeply fell in love with Marusya: "sometimes it was fun for her, so if she ran to her mother 
then and hugged her, she would get bored five times and wiped her tears with a handkerchief, and her father would like to dissolve her sorrows; then he smiled, then he was ashamed..." [9, 53]. Soon before the eyes of the reader the emergence of mutual affection for each other unfolds, and then it grows into passionate love: "I love you, Marusenka, with all my heart, I love you more than anything in the world" $[9$, p. 64]. The girl was very happy "her heart was beating like that she was shaking like a fever" $[9$, p. 64]. According to the melodramatic canons, Kvitka depicts mutual feelings a little bit too hyperbolized and this technique is used to influence on the readers emotions. O. Honchar noticed that "spiritually rich, consciously risen to the ideal by the writer the main characters embody high human qualities of simple people [4, p. 441]. Being too idealized and touching the characters evoke the feeling of admiration by the emotional reader.

The recipient is fascinated by the idealized feelings of a girl and a boy, but suddenly there was a sharp turnabout, which is a traditional element of melodrama. During the courtship Marusya's loving father, who seemed to appreciate Vasyl as the reader could notice did an incomprehensible and at first glance illogical, unjustified act for everyone: he ordered the suitors to pour a glass, which meant refusal. Nobody: neither Nastya, nor Marusya, nor Vasyl (nor the reader himself) understood what was happening and everyone was in despair. As it turned out later in the conversation between Naum and Vasyl, the father was afraid that "when the recruitment comes, they will probably shave Vasyl's forehead" and take him to the army while his daughter will become "neither a woman nor a widow" [9, p. 83]. Although the character wished his daughter only good, his unexpected act doomed her to misfortune and imminent death.

It is known that central themes of melodrama style prose are concentrated on the atmosphere of a house, love, marriage, collision of family life and sometimes death. So, we can find almost all of these in the compared prose. In both works in G. Kvitka's short story "Marusya" and in Dickens's novel "Domby and Son" there is a common central melodrama topic the love of young couple of Marusya and Vasyl (this theme is the main line of the story) and of Florence and Walter (which is not the main theme in the novel). The other similar theme is the conflict between the daughters and their parents: Marusya and Nahum; Florence and Mr. Domby (one of the main storylines) in the compared literary works.

The complex cold relationship between Mr. Domby as a father and his daughter Florence from Dickens's novel "Domby and Son", one of his storylines, helps to vividly recreate the picture of a deeply emotionally sad girl's life, embodied in the image of Florence. The reader is immediately filled with sympathy for the girl. Deprived of human warmth, lonely, alienated, she dreams of parental love. The stronger she wanted it; the further her father pushed her away. After all, she was a "fake coin" for him in matters of family business. Every night the girl quietly leaves her room, goes down the stairs and goes to the door of her father's office. "She leaned against them with her face and head and presses her lips lovingly" [10, p. 214]. Such a touching scene, indirectly, through external actions reveals the inner state of the character: Florence seeks refuge in his father's heart, but also wants to be a consolation for him, she needed it, "otherwise the poor crippled lonely heart will tremble like a bird with broken wings, and will break" [10, p. 211]. The author compares his heroine with a helpless creature of nature, a bird that can be broken by the anger and indifference of the "strong of this world". After all, the cruel, cold Mr. Domby did not comfort his little daughter, only at the end of the novel, after the vicissitudes of fate; he establishes a relationship with Florence, becomes a good grandfather and happily walks with his grandchildren. After all, melodrama is aimed at exposing human vices that disrupt the harmony of a world in which good is defeated by evil.

The theme of death as one of melodramatic topics is well presented in the compared works: in the novel by G. Kvitka "Marusya" and in the novel by Ch. Dickens "Domby and Son". The tragic moment of human death is created on the one hand to develop the plot and on the other to make the reader feel a deep sorrow, sympathy and compassion that is to evoke strong emotions and to intensify melodrama effect.

Unpredictable behavior of a loving father Naum who decided for himself what his daughter's life should be was followed by unhappy event. After a short meeting with her beloved Vasyl who was saying goodbye to her, Marusya felt that she didn't have to live any longer: "you leave me in the cemetery; you will find me in the cemetery" [9, p. 96]. Exhausted by the expectation of a loved man from a long travel, the girl was caught by the rain, soaked to the skin, fell ill and died. Deeply saddened by the loss of his beloved girl a young man condemns himself to the life of a monk. So, a bad will of a father is regarded as not honest deed by the reader which caused the tragedy and the educational value of the episode is brought to the surface: morality is defeated by immorality. Using the effect of a contrast when ethical heroes are opposed to cunning ones the G. Kvitka-Osnovianenko could influence on the emotionality of the recipient.

Dickens liked crying over the fate of his characters himself as he wrote in his letter to John Foster [12] and was skillfully able to evoke sympathy in his reader. The image of Florence is also associated with the death of loved ones: first her mother and then her brother Paul. She had a hard time with those losses, often mentally being with Paul, looking for a piece of mind as he was "the only friend and companion of her unhappy childhood" [10, p. 47]. Researcher Sally Ledger wrote that "one of the most affecting tableaux in Dickens's fiction is in the fifth monthly instalment of Dombey and Son when the "swift river" finally bears young Paul Dombey out into the ocean that has so preoccupied him throughout his short life" and he also noted that Dickens's friend Lord Jeffrey wrote to the writer: "I have so cried and sobbed over it last night, and again this morning; and felt my heart purified by those tears, and blessed and loved you for making me shed them" $[13,1]$.

Lonely Florence wandered around the house, falling on the bed under the influence of painful memories and sobbing bitterly, "finding no comfort - nothing but bitter and cruel longing" $[10$, p. 211]. The image of the girl is similar to the "angel of death", which embodies the philosophical rhetorical question: "Would it not be better for her to be lonely, unhappy, to be where now those whom she loved and who loved her?" [10, p. 211]. Such mental suffering of the girl, restlessness, alienation from the world of adults around her, shows the complicity in her fate and at the same time arises the condemnation of cold and cruel characters by the recipient.

G. Kvitka-Osnovyanenko and Ch. Dickens managed to show the essence of the existence of the "little woman" with his inner world, feelings; a person who lives in his closed space: either in the native Ukrainian village, or in the English "house like a fortress". The common feature is the image of a positive idealistic heroine with the high moral and ethical qualities which are hyperbolized 
to create the contrast between good and evil due to melodrama style canons. The technique of the emotional state of the character transmission through their speech, actions, movements, gestures, eye expressions, facial expressions make the reader penetrate into the feelings of the characters. Presence of intrigue; intense vicissitudes which happen in the characters' life also belong to the means of melodrama style prose and, consequently, the sentimental effect is created as the feelings of the recipient are sharpened and the audience unconsciously becomes an accomplice in the actions of the work.

The theme of love, house atmosphere, misunderstanding between daughters and parents, family collisions, death are well presented in compared literary works. As it is known that such ontological motives belong to the usual themes of melodrama style. Both authors refer to these common human events, feeling and moods to evoke sentimentality, sympathy and compassion to create the shield to help to resist the cruelty, rationalism and pragmatism of economically and industrially rapid-paced society in the beginning of capitalism in Ukraine and developing of it in England. Summing up we may remark that both Ukrainian and English literature successfully fit into the literary process of that time and the Ukrainian literature is represented as rightfully equal counterpart of world literary process.

\section{References:}

1. Remak Henry G. Literary Comparative Studies: its Definitions and Functions. Anthology / ed. By Dmytro Nalyvayko. Kyiv: Mohyla Academy, 2009. $487 \mathrm{p}$.

2. Дюришин Д. Теория сравнительного изучения литературы. Перевод со словацкого. Москва : Прогресс, 1979. 319 с.

3. Куліш П. Вибрані твори. Київ : Дніпро, 1982. 492 с.

4. Українська літературна енциклопедія / Ред. О. Дзеверіна, Г. Вервеса, О. Гончара. Вип. 2. Київ, 1990. С. 440.

5. Axton, William F. "Circle of Fire: Dickens' Vision and Style and the Popular Victorian Theater". Literature in English, British Isles. V. 26. Kentucky: The University Press, 1966. 312 p.

6. Garis Robert. The Dickens Theatre, a Reassessment of the Novels. Clarendon Press, 1965. 259 р.; Наливайко Д. Спільність і своєрідність: українська література в контексті європейського літературного процесу. Київ : Дніпро, 1988. 393 с.

7. Українка Леся. Літературно-критичні та публіцистичні статті.

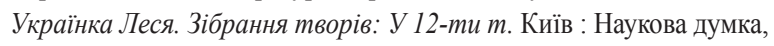
1977. T. 8.317 c.

8. Шахова К. Смуток і сміх Чарльза Діккенса. Нариси творчості зарубіжних письменників-реалістів XIX-XX cm. Київ, 1978. C. $15-23$.

9. Квітка-Основ'яненко Г.Ф. Вибрані твори. Київ : Дніпро, 1987. $312 \mathrm{c}$.

10. Dickens, Charles. Dombey and Son. Wordsworth Classics, $1995.878 \mathrm{p}$.
11. Ljustina Charlotte. Florence's Internal Strength and Power in Charles Dickens' "Dombey and Son", Munich, GRIN Verlag, 2013. URL: https://www.grin.com/document/307718

12. Foster John. The Critical Heritage, ed. by Philip Collins. London: Routledge and Kegan Paul, 1997. P. 345.

13. Ledger Sally. Dickensian Melodrama: A Reading of the Novels. Publisher: University of Kansas, 1978. 14 p.

Богачевська Л. О. Опис жіночих образів та їх долі в українській та англійській прозі в стилі мелодрами (порівняльно-типологічний аспект творів Г. КвіткиОснов'яненка «Маруся» та Ч. Діккенса «Домбі та син»)

Анотація. Поглиблене дослідження літературних явищ різних культур, взятих разом для аналізу, завжди $\epsilon$ цікавою темою для подальшого вивчення, що може дати нам зрозуміти, що літературний процес відображає сучасну реальність у всіх іiї аспектах, і їхнє проникнення у твори мистецтва унікальний персонаж, який являє особливий інтерес. Цитати літературознавців стосовно деяких письменників належать до контактно-генетичних зв'язків і дають досліднику імпульс для вивчення літературних творів на типологічному рівні. Вислови українського літературознавця П. Куліша виявляють деякі зв'язки та дають нам основу для дослідження. Таким чином, метою статті $\epsilon$ пошук подібних та різних особливостей прози в стилі мелодрами Г. Квітки-Основ'яненка «Маруся» та Ч. Діккенса «Домбі та син». Ці прозові твори різні за жанром (новела та роман) та за розміром, але загальні риси стилю мелодрами дають нам змогу дослідити їх на типологічно-порівняльному рівні. Англійські та українські митці були майже сучасниками (Ч. Діккенс, 1812-1870; Г. Квітка, 1778-1843), тому недивно, що їх твори характеризуються спільними рисами мелодрами та сентиментальності, які набуті завдяки “соціальним" та "психологічним" аспектами дійсно, що їх увібрали у творчість митці, а саме любов до театру. Головними героями аналізованих творів $€$ жіночі персонажі: Маруся та Флоренс, які дуже схожі за психологічними особливостями, такими як непрактичність, погана адаптація до життя, мрійливість, моральна чистота, емоційне захоплення добрими речами. Це особливий тип літературного характеру жінки, яка не має виконувати жодної соціально-політичної ролі в суспільстві і належати до свого дому. Центральні теми прози в стилі мелодрами відомі як онтологічні мотиви: народження, стосунки з батьками, кохання, колізії в сім’ї, смерть; передача емоційного стану персонажів через їх висловлювання, а також за допомогою образів дій, рухів, жестів, міміки очей, міміки змушує читача проникнути в почуття персонажів і співпереживати їм, отже, створюється мелодраматичний ефект - аудиторія несвідомо стає частиною дій.

Ключові слова: контактно-генетичні зв'язки, типологічна площина, мелодраматизм, сентименталізм, онтологічна тематика. 